\title{
Application of three dimensional teaching method in histology and embryology course
}

\author{
Xudong Chen ${ }^{1,}$, Xinyu Hua ${ }^{1}$ \\ ${ }^{1}$ Luohe medical college, Luohe, 462000, China \\ aEmail:573373763@qq.com
}

Keywords: Histology and Embryology, Three-Dimensional Teaching, Mobile Learning

Abstract: In order to improve the learning effect of histology and embryology course of higher vocational college students, the application of three-dimensional teaching method in histology and embryology teaching was explored. The results showed that the scores of the students in the group and the group were higher than those in the normal group. The teaching method can improve students' learning enthusiasm, students' ability of thinking and thinking, as well as the basic theoretical knowledge, and can meet the needs of lifelong learning in the learning society.

\section{Introduction}

Histology and embryology, as a basic medical science, mainly deals with the microscopic structure. At present there are many problems: the old teaching methods, cramming education teaching occupied the classroom, result in students interested in tissue embryology is not high[1]. In order to achieve good teaching effect, cultivate students' ability to analyze and solve problems, this paper will explore the application of three-dimensional teaching method in the teaching of histology and embryology of clinical specialty.

In recent years, with the development of wireless technology and handheld portable devices, people have made great changes in social and economic life style, their powerful features allow users to easily communicate with each other[2]. The emergence of mobile learning is in full compliance with the law. The United Nations educational, scientific and cultural organization since 1972 advocate life-long learning is the need to learn to survive, the European Union is information and computer technology application and how to learn is the key to the survival and competition in modern society need capacity. A learning society in the social environment of lifelong learning determines the innovations on their ways of learning, mobile learning can help people achieve the goal of continuous learning.

With the national emphasis on higher vocational education, the traditional teaching mode, teaching methods and teaching methods can not meet the requirements of modern teaching. Therefore, we should pay attention to the cultivation of students' learning ability, innovative spirit and creative ability, so that students can learn independently. Exam-oriented education can not meet the demand for talents in the new century, build a new type of histology and embryology teaching mode is the trend of The Times[3].

\section{Research object and research methods}

Randomly selected 2 class from grade 2016 of three years clinical specialty ,the number of 
students were 165 and 166, one class was randomly assigned to the experimental group and the other one as the control group. There was no significant difference in the total score and sex ratio between the two classes $(\mathrm{P}>0.05$ ). There are go all the way in courses teachers, teaching content, teaching schedule and the number of Class hours in two classes.

Group adopts the three-dimensional teaching method in teaching, A new synthesis method of teaching was adopted, which including classroom teaching, micro course Network Teaching and the test of questionnaire star test. Details are as follows: 1 . Before class, the corresponding sections of the micro lesson video through the network to the students, the students watch the video micro class in their spare time to use the network, preliminary master the knowledge points, and the problems in the study, through the QQ or WeChat group with classmates or ask the teacher.2. Ten minutes before the class for the last class to grasp the content of small roll star,as long as the students sweep using a mobile phone, fill in your student ID and name you can log on to do, after the completion of click Submit, instant results generated. Teachers focus on the traditional teaching of multimedia teaching in the class key problems, systematic comb all the class content, through elaborate design a series of logic problems, on the basis of these problems in the teaching. 3. After class, in addition to let the students finish the preview study the next new lesson at the same time, but also do a good job of learning the content of the review to consolidate, to deal with the next class of questionnaire star test.

Through teaching and learning, mobile learning, learning and the combination of measurement, highlight the cultivation of learning ability。Through the combination of "before class, class and after class", we should strengthen the cultivation of innovative ability, and realize the application of three-dimensional teaching system of histology and Embryology. Widely used in the control group used in colleges and universities of traditional classroom teaching methods, namely teachers with the help of multimedia, to review the last lesson before the relevant theoretical knowledge, and explain the teaching content, the focus of the whole teaching process with the teacher, the students listen to the old model. Theory course schedule of the two classes are exactly same and arrange to have classes in the first semester. The theory exams are close books and notes,the maximum mark is 100. After the course, around two kinds of teaching mode for middle school students learning effect and study, the questionnaire survey to 331 papers were issued, 331 valid papers taken back.

\section{Data processing and the results of the study}

All the questionnaire data, the statistical calculation of the measurement data are completed by SPSS17.0 software. 


\subsection{Two kinds of teaching methods, students' learning satisfaction survey are shown in table 1}

Table 1 Investigation on the satisfaction of two groups of students in the teaching of histology and Embryology (\%)

\begin{tabular}{|c|c|c|c|c|c|c|}
\hline \multirow{2}{*}{$\begin{array}{l}\text { Survey } \\
\text { items }\end{array}$} & \multicolumn{3}{|c|}{$\begin{array}{l}\text { Experimental } \\
\text { group }\end{array}$} & \multicolumn{3}{|c|}{$\begin{array}{l}\text { Control } \\
\text { group }\end{array}$} \\
\hline & satisfaction & insentience & unsatisfy & satisfaction & insentience & unsatisfy \\
\hline $\begin{array}{l}\text { Classroom } \\
\text { form }\end{array}$ & 95.2 & 4.8 & 0 & 73.2 & 20.3 & 6.5 \\
\hline Teaching & 99 & & & 72.1 & & 16.9 \\
\hline $\begin{array}{l}\text { Methods } \\
\text { diversification }\end{array}$ & & 1 & 0 & & 11 & \\
\hline $\begin{array}{l}\text { Modern } \\
\text { teaching } \\
\text { technology } \\
\text { use }\end{array}$ & 96.3 & 3.7 & 0 & 65.2 & 18.3 & 15.5 \\
\hline $\begin{array}{l}\text { Degree of } \\
\text { knowledge }\end{array}$ & 90.5 & 9.5 & 0 & 72 & 22.5 & 5.5 \\
\hline $\begin{array}{l}\text { Help to } \\
\text { the future }\end{array}$ & 96.7 & 3.3 & 0 & 83 & 12.2 & 4.8 \\
\hline Self-learning & 93.4 & & & 71.5 & & 5.5 \\
\hline $\begin{array}{l}\text { Ability } \\
\text { training }\end{array}$ & & 5.6 & 1 & & 23 & \\
\hline $\begin{array}{l}\text { Cultivation of } \\
\text { learning interest }\end{array}$ & 93.6 & 4.2 & 2.2 & 65.7 & 22 & 12.3 \\
\hline $\begin{array}{l}\text { Degree of } \\
\text { satisfaction }\end{array}$ & 94 & 3.6 & 2.4 & 82 & 15.6 & 2.4 \\
\hline
\end{tabular}

\subsection{Theoretical results of two classes are shown in table 2}

Table 2 Theoretical results of two classes $(\bar{x} \pm s)$

\begin{tabular}{ccc}
\hline class & $n$ & theoretical results \\
\hline Experiment & 165 & $90.12 \pm 3.23^{\triangle}$ \\
Control & 166 & $80.48 \pm 2.26$ \\
\hline
\end{tabular}

${ }^{\triangle}$ VS control class, $p<0.05$

\section{Discussion}

With the coming of the era of $4 \mathrm{~g}$ networks and cloud technology, the rapid development of mobile technology, all walks of life have been fully into the network construction, the development of education informationization is very quickly, fragmentation and mobile learning has gradually become the mainstream[4-5]. 2013 science and technology division of the Ministry of Education officially proposed in 2015 the basic realization of "School Link broadband networks, high-quality resources through classes, online learning space for everyone to pass". At present, our school has a 
complete coverage of the new and old campus wireless network has been successfully completed work.

Histology and embryology is an important medical morphology, anatomy is thorough, is the foundation of students' physiology and pathology study must grasp the medical term a lot in this class, micro structure and related functions, and most of the students think the curriculum content is abstract, boring, difficult to understand and remember. With the help of information technology, it is very important to construct a new teaching model of histology and Embryology theory, which can stimulate students' interest in learning, cultivate students' ability of active learning, and enhance their learning effect.

\subsection{Network timely delivery micro lessons before class}

Combined with many students in our school and the level of knowledge structure is not clear, the histology is a form of science, to see the microscopic structure of the microscope, coupled with the knowledge of the organization and Embryology trivial difficult to remember the actual situation.Department teachers use a variety of software, collect the material, carefully recorded in typical images, text, animation, micro course voice and plain as a whole, for the students before class through the network learning. Students can through the network platform, such as QQ and WeChat group to prepare the puzzled problems to communicate with solutions, necessary to carry on the real-time answer to the teacher. From the questionnaire data analysis in table 1 and table 2 theoretical results can be seen that the experimental class students on the course of satisfaction were better than that in comparative classes, and the difference was statistically significant, which indicates that the application of micro three-dimensional teaching mode in the network course obtained the praise of the students, promote the interest in learning,enhance learning effect.

\subsection{Psychological principles was used in classroom teaching to fully mobilize students' interest in learning}

Using the principle of primacy effect to stimulate students' interest in histology and embryology [6].Psychology thinks that the human brain to initial information often impressed, this is called primacy effect, which is usually says first impression. According to the principle of psychology, in the teaching of histology and embryology, the author attaches great importance to the teaching of each theory class. For example, in order to avoid the endocrine system in order to avoid the "class we all want to learn is the endocrine system", The author combines the condition of real life common rhetorical questions such as "life everyone seen high giant height more than ordinary people, and some are pocket etc ? The students responded quickly and responded positively. This relates to the content of the learning today. At this time the students will suddenly realize that the first time in class, the first impression of the importance of the system, which plays an important role in improving students' interest in learning.

\subsection{Classroom setting questionnaire star test, consolidate the theoretical knowledge}

Due to the nature of the course, students often feel the difficulty of learning histology and embryology, and three year medical students learning task is relatively heavy, less class hours. If all the knowledge all concentrated in the final weeks to review, one is the study pressure big, the second is the learning effect is not ideal. We recommend students to periodically review the learned knowledge, namely every once in a while review and organize the knowledge in knowledge into small module; Then gradually integrating these little knowledge module, form a larger knowledge module. So, when at the end of the semester to form a knowledge system, basically review is very 
convenient and easy. The questionnaire star, is a professional platform for the online questionnaire survey, evaluation, voting, compared with the traditional survey method, questionnaire star has the advantage of quick and easy to use and low cost. Take classroom teaching as an example: questionnaire survey, online examination and so on are most common [7]。 In order to urge students to study regularly, we designed a questionnaire in the theory class. The results of the study show that the experimental class with the new teaching mode of the classroom using the questionnaire of the star test, the theoretical results are significantly higher than the control group $(\mathrm{P}<0$. 05). The advantages of the questionnaire may be that the knowledge of the contents of the scattered assessment, each content is less, to avoid the phenomenon of temporary assault before the final exam, students are easy to accept, and easy to succeed. Educational psychology shows that the appropriate dispersion practice is superior to the excessive concentration, and the appropriate dispersion exercises make the practice better. Stage of learning success is enough to make the students be satisfied, which is one of the students willing to learn. Students can also find their own shortcomings in each quiz, identify gaps, so that learning more targeted and can stimulate the fighting spirit.

\section{Acknowledgement}

In this paper, the research was sponsored by the education technology and equipment and practice education research project topics in Henan Province In 2015 (Project No. GZS112)

\section{References}

[1] Jun Xiong,Kaihong Ji,Ling Yang,et al. Reform and practice of histology and embryology teaching. Journal of shanxi medical university [J].2010,12:338-341.

[2] Shuying Zhuang. The application of mobile learning model, building three-dimensional teaching system. Journal of jilin radio and TV university [J].2013,5: 85-86.

[3] Hongying Zhang,Yuan Zou, Jianing Zhang,et al. Build training innovative practice ability of medical morphological three-dimensional teaching system . Chinese higher medical education [J].2012,11: 81-83.

[4] Yunlong Lei,Ying Zhang, Dongchun Zhang,et al. Application of micro in medical biochemistry teaching . Theory and practice of medicine [J].2016,29: 414-420.

[5] Yichuan Zhang,Yangyi Qian. Development and application of micro course resources at home and abroad. Journal of Distance Education[J].2013,31: 26-33.

[6] Wei Yang. Application of mind mapping in histology and Embryology Teaching. Science and technology information [J].2016,1: 91-93.

[7] Xiaoli Dai. The application of questionnaire star in the classroom teaching reform. Audiovisual education of primary and secondary schools [J].2016,1: 91. 